Supporting Information for

\title{
Algae-Powered Sustainable Community Design Life Cycle Assessment and Techno-economic Analysis
}

Andrew P. Bessette, Ben J. Stuart, Eleazer P. Resurreccion, Sandeep Kumar

21 pages, 11 tables, 3 figures

Table of Contents

1. MODEL OVERVIEW

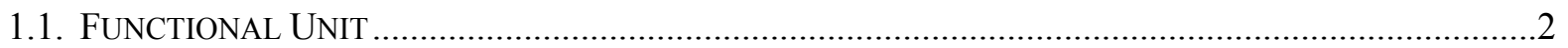

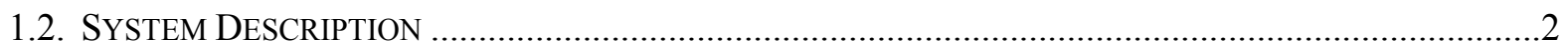

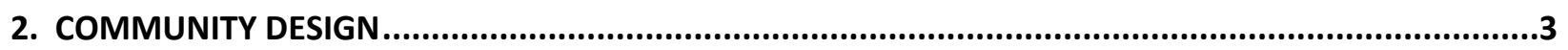

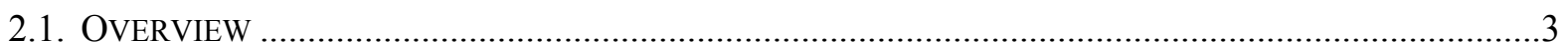

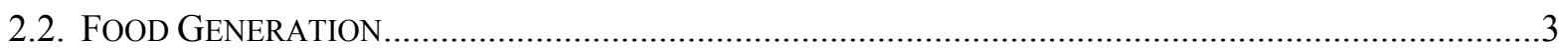

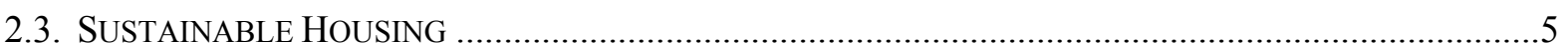

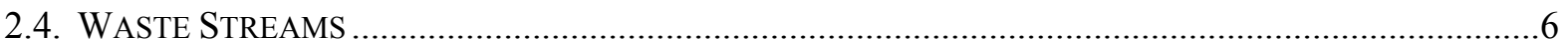

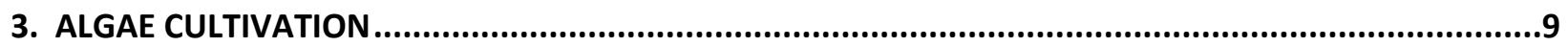

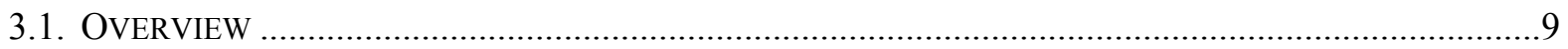

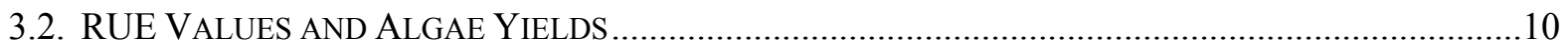

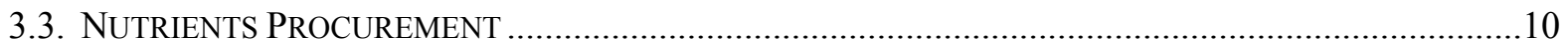

3.4. GENERIC WATER BALANCE ................................................................................... 11

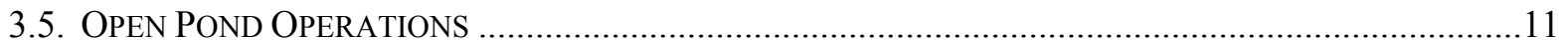

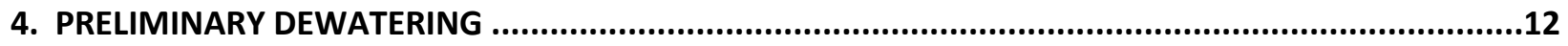

5. HOMOGENIZATION AND LIPID EXTRACTION .............................................................12

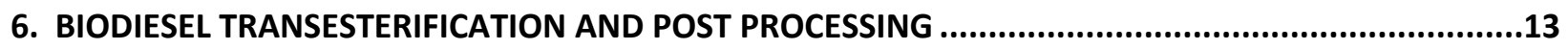

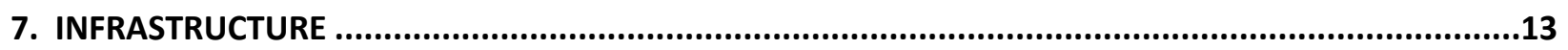

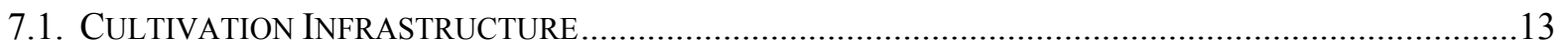

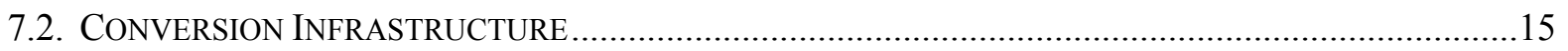

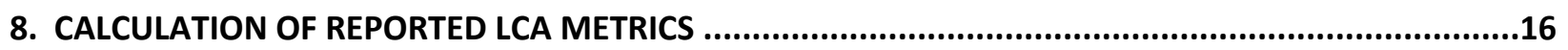

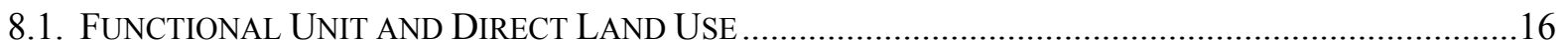

8.2. ENERGY RETURN ON (ENERGY) INVESTMENT (EROI) ................................................... 16

8.3. NET GLOBAL WARMING POTENTIAL (NGR) .............................................................. 16

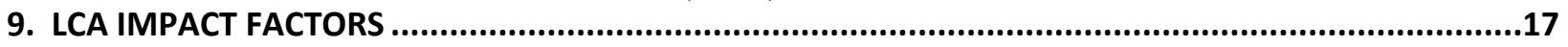

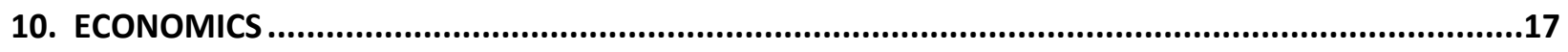

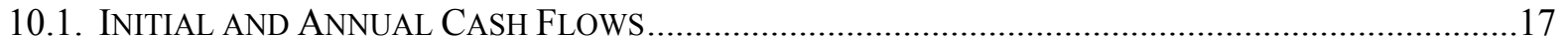

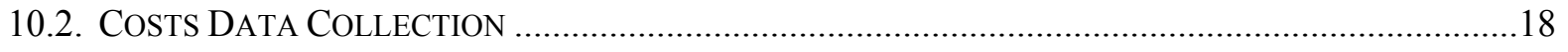

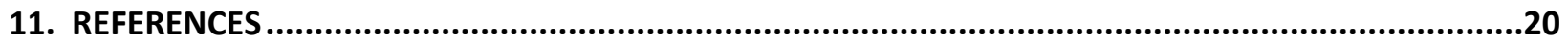

\section{Model Overview}

The life cycle assessment (LCA) models for this study were built in spreadsheet format using Microsoft Excel in conjunction with the Crystal Ball predictive modeling suite. This add-in for Microsoft Excel facilitates Monte Carlo analyses for complex systems by defining statistical distributions for input parameters. The program automatically samples from each input distribution and generates distributions of selected output parameters (i.e., 'forecasts'). The Monte Carlo analysis was conducted using 10,000 
trials. From earlier work conducted by Clarens et al. $(2011)^{1}$ and Resurreccion et al. $(2012)^{2}$, increasing the number of trials to 100,000 model 'runs' does not significantly change model results. All material, energy, and heat inputs were determined using literature values and first-principles engineering calculations. Environmental burdens associated with these inputs were calculated using impact factors obtained from the Ecoinvent ${ }^{\circledR}$ LCA database, as accessed using SimaPro v8. Our model outputs include two environmental impacts: net energy use (in MJ) and global warming potential (GWP) (in kg carbon dioxide equivalents, "kg CO2 eq").

\subsection{Functional Unit}

This model simulates a rural community. The rural town of Fairburn, which is located in the greater Atlanta region has been chosen based upon the research conducted by Georgia Tech University under the direction of Dr. Ben Stuart ${ }^{3}$. The community has a population of 902 people based on calculations published by Yang et al., 2018 ${ }^{3}$. The functional unit (FU) for this LCA study is the energy required to sustain the community of 902 people. This value is calculated in section 2.3 and assumed to be 20,000 $\mathrm{MJ} / \mathrm{yr}$ to provide a buffer for error. This unit represents the required energy and food products required to sustain the community as well as the waste stream generated from those individuals and processes required to keep the community functioning. The energy content of Scenedesmus sp. is assumed to be 23 $\mathrm{MJ} / \mathrm{kg}^{4}$. The areal productivity of Scenedesmus sp. is assumed to be $41.6 \mathrm{Mg} / \mathrm{ha}^{2,5}$.

\subsection{System Description}

Figure S1 describes the overall process of the sustainable community design managed through algae cultivation. The community is designed around a rural community with a population of 902 people. The community is sustained with food through aquaculture, poultry and dairy products, and terrestrial crops. Electricity and heat are provided through solar thermal, wind (optional), photovoltaic arrays, biodiesel generators (optional), and combustion gas turbine generators through the combustion of biogas. The housing is energy efficient sustainable housing. The algae is cultivated in open raceway ponds. Waste streams are segregated and processed through anaerobic digestion which produces the biogas and also produces a nutrient rich liquor which is disinfected and used as a nutrient source for the algae cultivation. A solid product is also produced as a co-product which can be used as a soil amendment for terrestrial agriculture. Nutritional sustainment for the community is provided by aquaculture, poultry and dairy products and fruits and vegetables produced from terrestrial agriculture. The following processes are included in the LCA: upstream manufacture of material and energy inputs, cultivation of algal biomass, pre-processing and concentration of algal biomass, lipid extraction of algal biomass, and conversion of algae biomass into usable energy product and usable co-products. Process inputs include freshwater culture medium, energy, heat, nutrient recycle, and community municipal solid waste (MSW). Process outputs include both energy (algae biodiesel or methane derived bioelectricity) and wastes (purge water and land filled activated sludge). 


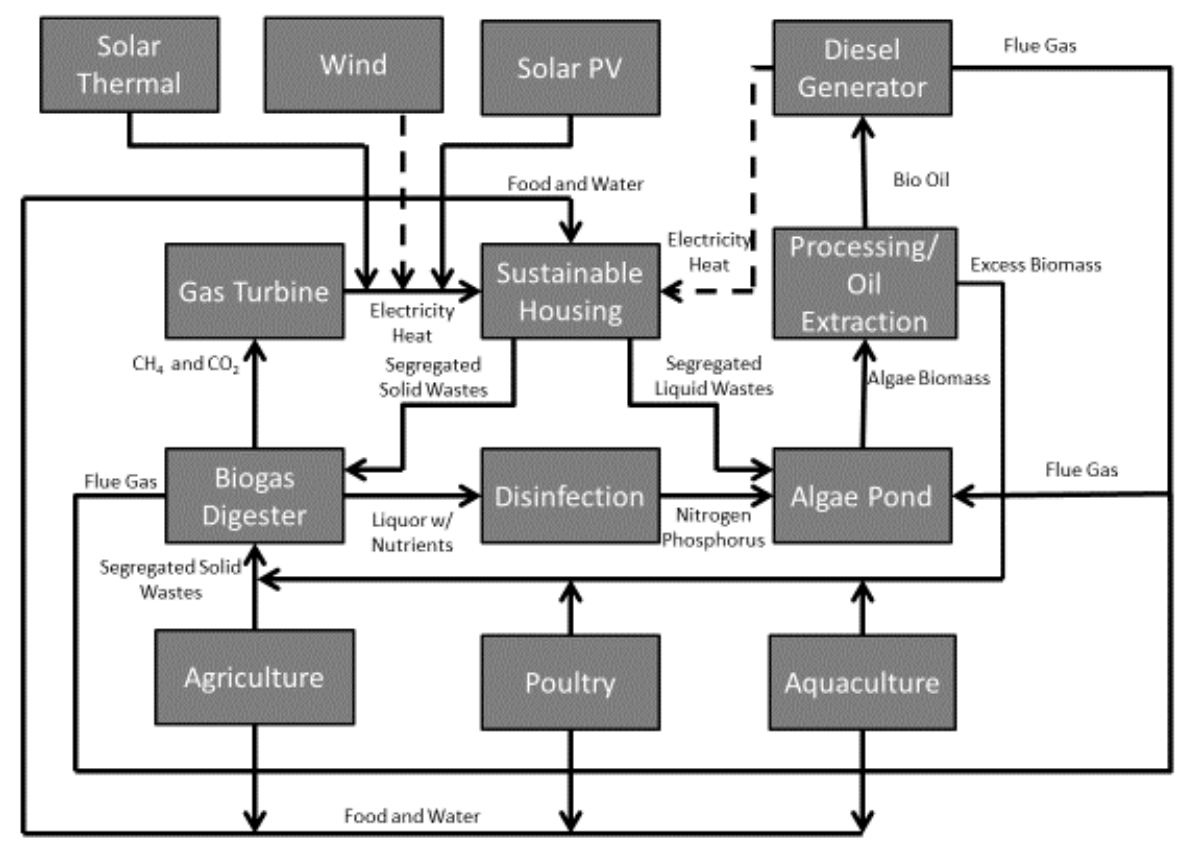

Figure S1. Overall schematic for the life cycle assessment (LCA) and techno-economic analysis (TEA) of the sustainable community design managed through algae cultivation.

\section{Community Design}

\subsection{Overview}

The rural community of Fairburn has a total residential area of $1,726,329 \mathrm{~m}^{2}$. Of that, $52,813 \mathrm{~m}^{2}$ is consumed for residential building footprint according to GIS $^{3}$. That leaves $1,673,516 \mathrm{~m}^{2}$ available for the rest of the community functions. This model is based on a sustainable community therefore all agricultural, food generation, and energy generation must be considered in space planning. The community is provided with heat and electricity from solar photovoltaic arrays, solar thermal systems, and gas turbine generators. Wind and diesel generators are considered for alternative options. Fuel for the diesel generators is generated from biodiesel derived from algae grown in open pond systems. Fuel for the combustion turbine generators is provided from methane biogas produced from anaerobic digestion of MSW and lipid extracted algae (LEA) biomass. Food is sourced from terrestrial crops, fish, poultry, and dairy. The total ground space for each of these requirements in this neighborhood must be calculated in order to determine what amount of land is available for energy generation. Building energy use is calculated for the net community energy demand. In addition, waste streams must be evaluated for nutrient recycling and anaerobic digestion $(\mathrm{AD})$ potential biogas generation.

\subsection{Food Generation}

The average individual has a demand of 2,000 lbs. of food per year. The average individual's diet consists of $34.4 \%$ fruits and vegetables, $9.6 \%$ grains, $31.5 \%$ dairy, $5.5 \%$ fish (includes oils), and 10.8\% poultry ${ }^{6-7}$. The remaining fraction (other) is attributed to artificial sweeteners and similar products which will not be simulated in this model. With a population of 902 people, the community's food demand is shown in Figure S2: 


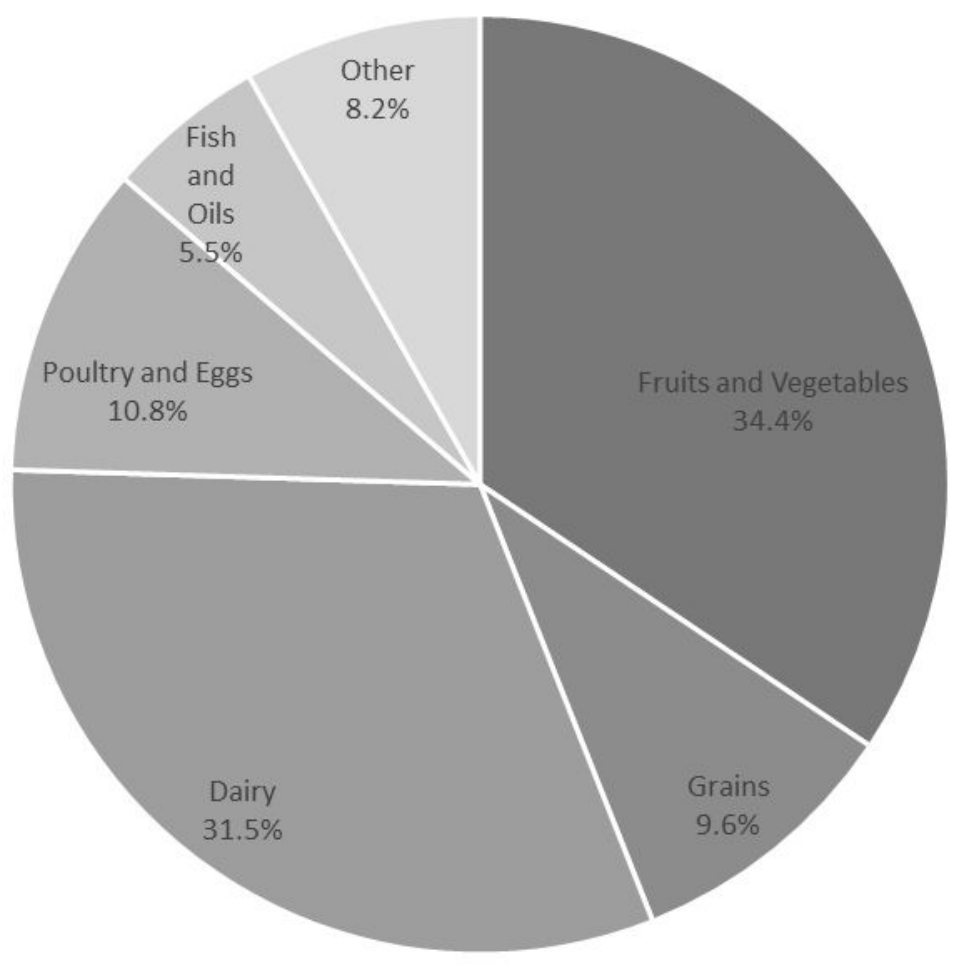

Figure S2. Average US food consumption

Based upon a population of 902 people, Table S1 shows the total demand of food based upon a 2,000 $\mathrm{lb} /$ year diet.

Table S1. Total annual demand of each food type for a 902-person community.

\begin{tabular}{cr}
\hline Food Type & Total Demand (kg) \\
\hline Fruits and Vegetables & 281,742 \\
Grains & 78,626 \\
Dairy & 257,990 \\
Poultry and Eggs & 88,454 \\
Fish and Oils & 45,046 \\
Other & 67,159 \\
\hline
\end{tabular}

Based upon the 2018 Georgia State Agricultural overview, the following fruits, vegetables, and grains are the most widely grown in the state and the land use associated with them is shown in Table $\mathrm{S} 2^{8}$. 
Table S2. Land use associated with Georgia grown crops

\begin{tabular}{cr}
\hline Fruits and Vegetables $(\mathrm{m} 2 / \mathrm{kg})$ & Grains $\left(\mathrm{m}^{2} / \mathrm{kg}\right)$ \\
\hline Peanuts $(2.01)$ & Corn $(0.84)$ \\
Watermelon (0.53) & Wheat $(2.78)$ \\
Peppers (0.30) & Rye (5.88) \\
Cucumbers (0.53) & Oats (2.08) \\
Beans (1.69) & \\
Cabbage (0.20) & \\
Peaches (0.51)
\end{tabular}

The average land use was calculated for fruits and grains and the land use for the animal products was sourced from Flachowsky et al. (2017) ${ }^{9}$. Table S3 shows the total land use requirement for the 902person community.

Table S3. Land Use requirement for the 902-person community

\begin{tabular}{cccc}
\hline Food Type & Total Demand $(\mathrm{kg})$ & Land Use $\left(\mathrm{m}^{2} / \mathrm{kg}\right.$ product $)$ & Land Use $\left(\mathrm{m}^{2}\right)$ \\
\hline Fruits and Vegetables & 281,742 & 0.82 & 231,028 \\
Grains & 78,626 & 2.90 & 228,015 \\
Dairy & 257,990 & 1.55 & 399,885 \\
Poultry and Eggs & 88,454 & 7.18 & 635,098 \\
Fish and Oils & 45,046 & 1.78 & 80,182 \\
\hline
\end{tabular}

The total agricultural requirement is $1,574,210 \mathrm{~m}^{2}$ based on the sum of the land use required for each of the products $^{8-9}$ in Table S3. The total available ground space after residential housing requirements calculated in Section 2.1 is 1,673,517 leaving a surplus of $99,307 \mathrm{~m}^{2}$ or 9.93 hectares after the 1,574,210 $\mathrm{m}^{2}$ agricultural requirement is deducted. This is the land that is available for algae cultivation in open raceway ponds and associated peripherals outside of the pond area. The peripherals around the pond area account for an additional $25 \%$ of space $^{10}$ (2.48 hectares) which reduces the available land to 7.45 hectares.

\subsection{Sustainable Housing}

The building energy use was calculated based upon Yang et al., 2018 ${ }^{3}$. The energy use intensity (EUI) was sourced from the Department of Energy Building Dataset ${ }^{11}$ for the Atlanta residential building type. The EUI and the total floor area of each building was calculated to yield the average energy use of residential buildings which was then used to calculate the cumulative energy use of the neighborhood using equation S1 below. The total floor area was found to be $69,735 \mathrm{~m}^{2}$ and the total annual residential building energy use was found to be 28,523 MBtu/yr (30,094 MJ/yr):

Equation S1

Annual Neighborhood Residential Building Energy Use = Annual Residential EUI $*$ Neighborhood Total Floor Area 
The utilization of energy efficient residencies has the potential to reduce total building energy consumption by up to $45 \%{ }^{12}$. This magnitude of reduction is accomplished through lighting improvements (high efficiency ballasts and bulbs and room sensors), radiant barrier insulation, argonfilled low-emissivity double paned glass windows, daylighting, energy efficient appliances and electronics, photovoltaic solar panels, and tankless hot water systems equipped with solar hot water preheat systems (reduces the energy consumption on the tankless by $50 \%$ annually ${ }^{12}$ ). With these improvements to building design, the total annual residential building energy use is reduced to 15,688 MBtu/yr (16,552 MJ/yr).

This model assumes 2.54 people per household ${ }^{13}$. This yields 355 households in the community. At an average electrical load of $16 \mathrm{~kW} /$ household $^{14}$, this equals a $5.7 \mathrm{MW}$ requirement for the entire community. At $\$ 1,021 / \mathrm{kW}$ for diesel generators ${ }^{15}$, this would cost $\$ 5.8 \mathrm{M}$ for the diesel generators. This study considers alternative options where diesel generators are purchased for emergency backup power at $50 \%$ of the average demand $(8 \mathrm{kWh} /$ household $)$ at a cost of $\$ 2.9 \mathrm{M}$. While diesel generators are operating, the algae cultivation ponds are supplied with $\mathrm{CO}_{2}$ rich flue gas at a rate of $663 \mathrm{~g} / \mathrm{kWh}^{16}$. If the generators are running at $80 \%$ capacity for 24 hours, it would produce $54,546 \mathrm{kWh}$ in energy or $36.15 \mathrm{Mg}$ $\mathrm{CO}_{2} /$ day. Wind turbines average a unit price of $\$ 3 / \mathrm{W}^{17}$ which can also be considered for augmented energy supply and increased community resiliency. Location must be carefully considered however because heavily forested areas compared to flat land or water can increase the roughness factor by up to $250 \%{ }^{17}$ thereby reducing the turbine power output.

\subsection{Waste Streams}

The annual residential municipal solid waste (MSW) per person in the city of Atlanta was found to be 272 $\mathrm{kg}$ /person based on the 2012 reported data of $191,414 \mathrm{mTons}$ ( $60 \%$ residential) by a population of 421,600 individuals' $\mathrm{kg}$ by using the following equation:

Equation S2

$$
\text { Annual Residential MSW per Person }=\frac{\text { Annual Total City MSW } * \text { Residential MSW Ratio }}{\text { City Population }}
$$

The town of Fairburn has a population of 902 individuals according to calculations by Yang et al., $2018^{3}$ which yields a total of $409,525 \mathrm{~kg}$ of municipal solid waste (MSW) per year when relatively compared to the total city of Atlanta of which, 245,715 kg is residential MSW. The density of residential MSW is approximately $300 \mathrm{~kg} / \mathrm{m}^{3}$ which yields $819 \mathrm{~m}^{3}$ of MSW waste per year or $2.24 \mathrm{~m}^{3}$ of MSW per day. This value is factored into the sizing of the anaerobic digestor (AD) along with the daily mass of algae biomass being processed in the digestor.

The composition of the total MSW can be seen in Figure S3 below. 


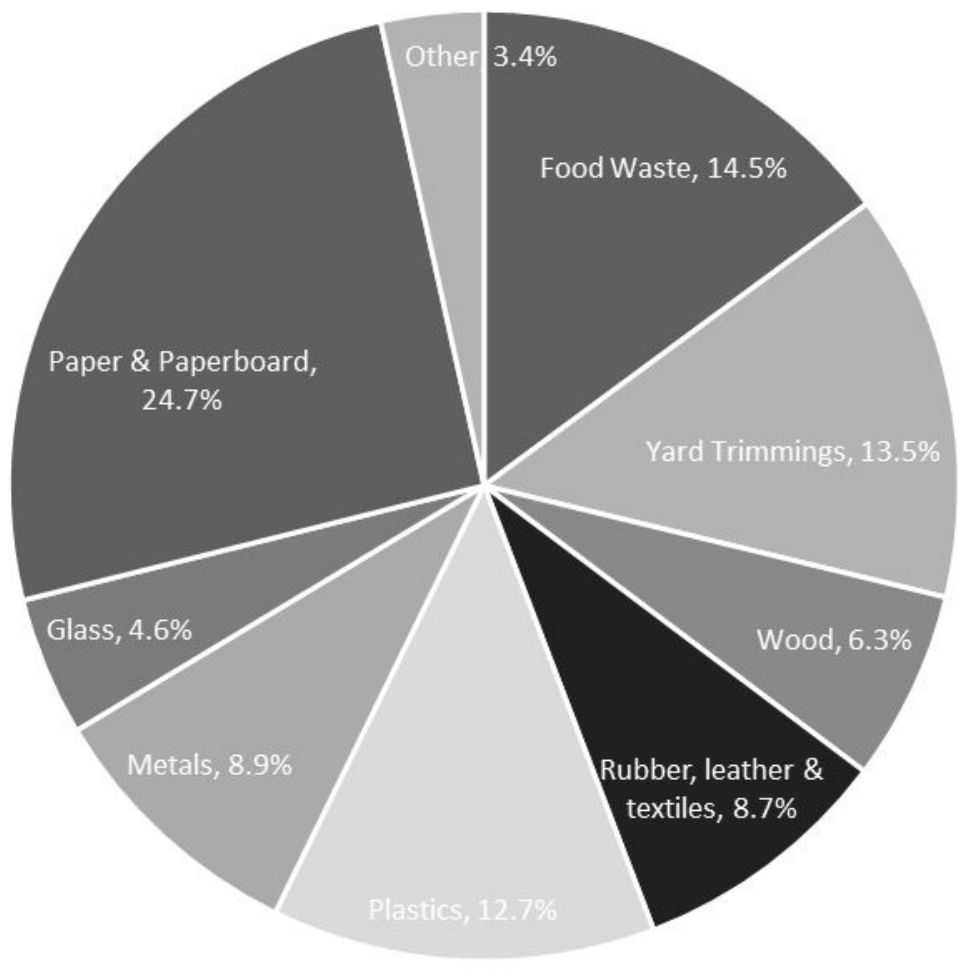

Figure S3. The City of Atlanta MSW characterization.

The organic portion of the waste stream is available for use as a feedstock for the algae cultivation system. The organics included in this model include paper \& cardboard, food waste, yard trimmings, and wood (57\%). This organic portion of the waste stream is fed into an AD which produces waste products in the form of a nutrient rich liquid effluent and a nutrient rich solid product used as a soil amendment. It also produces biogas which is an important energy source for the community. $1 \mathrm{~kg}$ of MSW volatile solids produces $468 \mathrm{~L}$ of biogas, $60 \%$ of which is methane ${ }^{18}$. The proportion of volatile solids in each portion of the organic waste stream can be seen in Table S4:

Table S4. Volatile solids portion of the organic waste stream categories

\begin{tabular}{cc}
\hline Waste Category & Volatile Solids \% \\
\hline Paper and Cardboard & $50 \%$ \\
Food Waste & $27.3 \%$ \\
Yard Trimmings & $46 \%$ \\
Wood & $42.5 \%$ \\
\hline
\end{tabular}

The volatile portion of the organic waste stream is what determines the amount of methane that is theoretically able to be produced. The mass of the volatile solids in the type of waste is found using Equation S2. 
Mass of Volitile Solid $=$ Mass $\%$ of Type of Waste $*$ Total Mass of Waste $*$ Volitile Solid $\%$ of Type of Waste

The total volatile solids for the year equals $25 \%$ of the total MSW.

The total amount of methane produced is based upon the percentage of each category of waste stream and the volatile fraction of each waste stream from Table S4. $1 \mathrm{~kg}$ of MSW produces $116 \mathrm{~L}$ of biogas which equals $69.43 \mathrm{~L}$ of methane for every $1 \mathrm{~kg}$ of MSW. In this modeled city, this yields 17,060,100 L (17,060 $\mathrm{kg} / \mathrm{yr}$ assuming a density of $1,000 \mathrm{~L} / \mathrm{kg}$ of methane) of annual methane production.

The liquid digestion effluent product produced from the anaerobic digestion process is to be used for a nitrogen and phosphorus source in the algae cultivation system. For the MSW, $75 \%$ of the N and $25 \%$ of the $\mathrm{P}$ are retained in the product ${ }^{1-2}$. Therefore, since the household waste stream contains $57 \%$ organic waste, this yields a total of $175,072 \mathrm{~kg} / \mathrm{yr}$ of $\mathrm{N}$ and $58,357 \mathrm{~kg} / \mathrm{yr}$ of P available for the algae cultivation pond found by using Equation S4.

Mass of Nutrient $=$ Organic Mass \% * Max(P Retainment \%,N Retainment \%) Equation S4

An additional waste stream is processed in the anaerobic digestion system which is the remaining biomass that is available after the harvested algae is dewatered and the lipids have been extracted, also known as lipid extracted algae (LEA). For the LEA, the removal efficiencies for algae biomass were derived from Clarens et al. $(2011)^{1}$ and Resurreccion et al. $(2012)^{2}$. The VSS removal efficiency is $41 \%$, the biogas methane fraction is $72 \%$, the biogas $\mathrm{CO}_{2} \%$ is $22 \%$, the $\mathrm{N}$ available in the digestion recycle is $75 \%$, and the $\mathrm{P}$ available in the digestate effluent is $25 \%$. This yields a total of $0.7 \mathrm{Mg} \mathrm{N} / \mathrm{ha}-\mathrm{yr}$ of and $0.05 \mathrm{Mg}$ $\mathrm{P} /$ ha-yr.

The post processing of the remaining mass after anaerobic digestion requires a solid/liquid separation process and is accomplished through belt filter pressing with an electricity demand of 25,569 $\mathrm{MJ} / \mathrm{ha}^{-\mathrm{yr}^{19}}$ derived from Soda et al. 2010. The liquids can be recycled to the algae pond and the solids can be used as a soil amendment. The solid digestate is used as a fertilizer supplement in terrestrial agriculture ${ }^{1}$. This solid product is to be used on the agricultural sites within the community. The digestate solid product is characterized by having a phosphorus content of $12 \mathrm{mg} \mathrm{P} / \mathrm{g}$ digestate and $42.5 \mathrm{mg} \mathrm{N} / \mathrm{g}$ digestate ${ }^{1-2}$. The bioavailability of the nutrients in the product is assumed to be $25 \%$ for $\mathrm{N}$ and $8 \%$ for $\mathrm{P}^{1-2}$.

Additional $\mathrm{N}$ and $\mathrm{P}$ are sourced from a conventional activated sludge wastewater treatment system for the incoming cultivation water which assumes a N content on $25 \mathrm{mg} / \mathrm{L}$ and a $\mathrm{P}$ content of $7 \mathrm{mg} / \mathrm{L}^{20}$. This yields a total of $1.3 \mathrm{Mg} \mathrm{N} / \mathrm{ha}-\mathrm{yr}$ and $0.4 \mathrm{Mg} \mathrm{P} / \mathrm{ha}-\mathrm{yr}$.

The total nutrient flows from waste streams can be seen in Table S5 below:

Table S5. Annual waste stream nutrient flows of MSW AD, LEA AD, and wastewater effluent

\begin{tabular}{crr}
\hline Waste Stream & \multicolumn{2}{c}{ Annual Production } \\
\hline & $\mathrm{N}(\mathrm{Mg})$ & $\mathrm{P}(\mathrm{Mg})$ \\
MSW AD (per yr) & 175.10 & 58.36 \\
LEA AD (per ha-yr) & 0.70 & 0.05 \\
WW Effluent (per ha-yr) & 1.30 & 0.40 \\
\hline
\end{tabular}


The total annual nutrient requirement per acre is $3.6 \mathrm{Mg} / \mathrm{ha}$ of $\mathrm{N}$ and $0.5 \mathrm{Mg} / \mathrm{ha}$ of $\mathrm{P}$ according to demand requirements summarized in Table S5 below. Excluding the MSW AD effluent, this leaves a deficiency of $1.6 \mathrm{Mg} /$ ha of $\mathrm{N}$ and $0.1 \mathrm{Mg} / \mathrm{ha}$ of $\mathrm{P}$. This is provided by the MSW AD effluent. Equation S5 used to find the maximum number of hectares of algae pond that the MSW AD effluent can support.

$$
\begin{gathered}
\text { Maximum Number of Hectares = Annual MSW } / \text { Nutrient Shortage Equation S5 } \\
\text { For N: } 109.44 \text { hectares } / \mathrm{yr}=(175.10 \mathrm{Mg} / 1.6 \mathrm{Mg}) / \mathrm{ha} \cdot \mathrm{yr} \\
\text { For P:583.6 hectares } / \mathrm{yr}=(58.36 \mathrm{Mg} / 0.1 \mathrm{Mg}) / \mathrm{ha} \cdot \mathrm{yr}
\end{gathered}
$$

The $\mathrm{N}$ in the MSW was found to be the limiting nutrient therefore a maximum of 109.44 ha can be used for algal cultivation. It was found in Section 2.2 that a maximum of 7.45 ha is available for cultivation after food production therefore the algae cultivation is unrestrained by waste streams.

The anaerobic digestion process requires heat and electricity. The electricity and heat demands were derived from Soda et al. (2010) ${ }^{19}$ and calculated to be approximately 38,000 MJ/ha-yr for electricity (Equation S6) and approximately 1,500 MJ/ha-yr for heat (Equation S7) using the following equations:

$$
\begin{gathered}
y=25876 x^{0.944} \quad \text { Equation S6 } \\
z=-5640 \ln (x)+27100 \text { Equation S7 }
\end{gathered}
$$

The methane which is produced is utilized in a combustion turbine generator to produce energy for the community. The combustion turbine generator is assumed to have an efficiency of $0.53^{21}$. The methane energy content is assumed to be $50 \mathrm{MJ} / \mathrm{kg}^{21}$. The methane combustion (MC) of the algae biomass was found to produce $287,551 \mathrm{MJ} / \mathrm{ha}-\mathrm{yr}$ of bioenergy and the MC of the MSW was found to produce 452,093 $\mathrm{MJ} / \mathrm{yr}$ of bioenergy $(17,060 \mathrm{~kg} / \mathrm{yr} * 50 \mathrm{MJ} / \mathrm{kg} * 53 \%)$.

The $\mathrm{MC}$ generates $\mathrm{CO}_{2}$ which is recycled to the algae cultivation. The amount of $\mathrm{CO}_{2}$ recycled is based off of a complete combustion using stoichiometric conversion $\left(44 \mathrm{~g} \mathrm{CO}_{2}\right.$ per $18 \mathrm{~g} \mathrm{CH}_{4}$ combusted). This yields $16 \mathrm{Mg} \mathrm{CO}_{2} /$ ha-yr for the algae derived combustion and $47 \mathrm{Mg} / \mathrm{yr}$ for the MSW combustion. AD also produces $\mathrm{CO}_{2}$ at a rate of $3.5 \mathrm{Mg} / \mathrm{ha}$-yr for the algae combustion and $10.4 \mathrm{Mg} / \mathrm{yr}$ for MSW AD.

There is also a waste stream generated from the food waste from the raw agricultural products that are not consumed, animal manure, and fish carcasses not consumed. It is assumed that these waste streams are utilized for animal feed and composing for returning required nutrients to the soil. Nigussie et al (2015) suggests that the internal agricultural demand for animal feed and soil amendment can be satisfied with intensified crop and livestock production ${ }^{22}$.

\section{Algae Cultivation}

\subsection{Overview}

The cultivation configuration assessed in this study was an open pond system. Algae yields for each of the evaluated systems were computed using the protocol of Clarens et al. $(2010 ; 2011)^{1,23}$, Resurreccion et al. $(2012)^{2}$, and Bessette et al. (2018) . This configuration is able to utilized otherwise un-productive land and has the economic potential to scale up to a full scale facility ${ }^{24}$. The outdoor open pond system 
modeled utilized Scenedesmus sp. The cultivation methodology and variables were held constant for each variation of the models evaluated.

\subsection{RUE Values and Algae Yields}

Algae yields for each of the evaluated systems were computed using the protocol of Clarens et al. (2010; 2011) $)^{1,23}$, Resurreccion et al. (2012) $)^{2}$, and Bessette et al. (2018) , whereby radiation use efficiency (RUE) is multiplied by photosynthetically active radiation (PAR). All atmospheric values for this study were based on data from sustained outdoor algae cultivation trials in open pond systems using the atmospheric conditions at the location of Roanoke, VA. Table S5 summarizes annual average algae and lipid yields.

Table S5. Summary of RUE values, lipid contents, biomass yields, lipid yields, and nutrient demands for this study. RUE and lipid content are "likeliest values" from respective triangular distributions. Biomass yield and lipid yield are annual averages, as taken from respective models. N (nitrogen), $\mathrm{P}$ (phosphorus), and $\mathrm{CO}_{2}$ demands are based on algae yields and assumed stoichiometry.

\begin{tabular}{lrrrrrrr}
\hline System & $\begin{array}{r}\text { Likeliest RUE, } \\
\text { g DW/MJ PAR }\end{array}$ & $\begin{array}{r}\text { Likeliest Lipid } \\
\text { Content, \% }\end{array}$ & $\begin{array}{r}\text { Biomass Yield, } \\
\mathrm{Mg} \text { DW/ha-yr }\end{array}$ & $\begin{array}{r}\text { Lipid Yield, } \\
\mathrm{Mg} / \mathrm{ha}-\mathrm{yr}\end{array}$ & $\begin{array}{r}\mathrm{N} \text { Demand, } \\
\mathrm{Mg} / \mathrm{ha}-\mathrm{yr}\end{array}$ & $\begin{array}{r}\mathrm{P} \text { Demand, } \\
\mathrm{Mg} / \mathrm{ha}-\mathrm{yr}\end{array}$ & $\begin{array}{r}\mathrm{CO}_{2} \text { Demand, } \\
\mathrm{Mg} / \mathrm{ha}-\mathrm{yr}\end{array}$ \\
\hline $\begin{array}{l}\text { Open } \\
\text { Pond }\end{array}$ & 1.40 & 13 & 41.6 & 4.7 & 3.6 & 0.5 & 111.7 \\
\hline
\end{tabular}

\subsection{Nutrients Procurement}

This model uses similar methodology and numerical values as Clarens et al. $(2010 ; 2011)^{1,23}$, Resurreccion et al. (2012) $)^{2}$, and Bessette et al. $(2018)^{5}$ for carbon dioxide $\left(\mathrm{CO}_{2}\right)$ utilization efficiency, compression energy requirement, and flue gas composition. The $\left(\mathrm{CO}_{2}\right)$ required for the microalgae cultivation is supplied from flue gas assumed to be co-located with the algae ponds. The flue gas is assumed to have a $12.5 \% \mathrm{CO}_{2}$ concentration based upon Kadam, $2002^{25}$. The flue gas requires compression in order to be delivered to the open pond. The work required to compress flue gas is 39 $\mathrm{kJ} / \mathrm{kg}$ flue gas ${ }^{1}$ or $314 \mathrm{~kJ} / \mathrm{kg} \mathrm{CO}$, since flue gas is only $12.5 \% \mathrm{CO}_{2}$. Equation used in calculating compressor energy requirement for gas delivery is:

$$
\mathrm{W}=\frac{\mathrm{C}_{\mathrm{p}} * \mathrm{~T}}{\mathrm{n}_{\mathrm{c}}}\left[\left(\frac{\mathrm{P}_{\text {out }}}{\mathrm{P}_{\text {in }}}\right)^{\left(\frac{v-1}{v}\right)}-1\right] \quad \text { Equation S8 }
$$

where: $\mathrm{W}=$ compressor energy requirement $(\mathrm{kJ} / \mathrm{kg})$

$\mathrm{Cp}=$ specific heat of $\mathrm{CO}_{2}(\mathrm{~J} / \mathrm{kg}-\mathrm{K})$

$\mathrm{T}=$ temperature $\left({ }^{\circ} \mathrm{C}\right)$

$\mathrm{n}_{\mathrm{c}}=$ compressor efficiency $(0.85)$

$\mathrm{P}_{\text {out }} / \mathrm{P}_{\text {in }}=$ minimum pressurization for pumping $\mathrm{CO}_{2}$ as liquid (2)

$\gamma=$ compressor work equation constant (1.27)

Due to atmospheric loses, the carbon dioxide utilization efficiency is assumed to be $0.7^{2}$. The final amount of flue gas required and the subsequent energy demand for pumping were determined based on annual algae yield calculated using meteorological conditions in Virginia. The amount of $\mathrm{CO}_{2}$ that the algae cultivation requires per hectare is $112 \mathrm{Mg}$ /ha-yr. The amount of $\mathrm{CO}_{2}$ supplied through $\mathrm{AD}$ and $\mathrm{MC}$ of algae biomass is $19.5 \mathrm{Mg}$ /ha-yr. The amount of $\mathrm{CO}_{2}$ produced through $\mathrm{AD}$ and $\mathrm{MC}$ of MSW is 13.9 
$\mathrm{Mg} / \mathrm{yr}$. The total amount of $\mathrm{CO}_{2}$ which must be purchased is $87.1 \mathrm{Mg} /$ ha-yr for a 7.45 ha algae cultivation footprint.

Nutrient demands were computed stoichiometrically, based on the so-called Redfield ratio $\left(\mathrm{C}_{106} \mathrm{H}_{181} \mathrm{O}_{45} \mathrm{~N}_{15} \mathrm{P}\right)^{26}$ and model-computed algae yields for each system using the same protocol as Clarens et al. $(2010 ; 2011)^{1,23}$, Resurreccion et al. $(2012)^{2}$, and Bessette et al. (2018) . Resulting values are summarized in Table S5. It was assumed that nitrogen $(\mathrm{N})$ and phosphorus $(\mathrm{P})$ sources are delivered by effluent from the $\mathrm{AD}$ process and treated wastewater effluent. Table $\mathrm{S} 6$ summarizes a water balance for all models.

\subsection{Generic Water Balance}

Table S6. Water balance for algae cultivation, conversion, and post-processing. Q's are volumetric flow rates of algae slurry (algae + water) in units of L/ha.

\begin{tabular}{lr}
\multicolumn{1}{c}{ Algae } & OPEN POND \\
\hline Raw well water intake & $9,240,308$ \\
Influent to cultivation & $51,264,922$ \\
Effluent from cultivation & $43,123,881$ \\
Effluent from autoflocculation & $3,920,353$ \\
Effluent from thickening into homogenization & 388,503 \\
Effluent from homogenization into lipid extraction & 388,503 \\
Effluent from lipid extraction into anaerobic digestion & 383,350 \\
Influent to Dewatering & 355,614 \\
Water content of sludge & 35,401 \\
Recycle from dewatering & 320,213 \\
Purge & $1,030,976$ \\
Recycle from thickening & $3,531,849$ \\
Recycle from autoflocculation & $39,203,528$ \\
Recycle before purge & $42,735,377$ \\
Recycle after purge & $41,704,402$ \\
Evaporation from cultivation/cooling pond & $8,173,931$
\end{tabular}

\subsection{Open Pond Operations}

The open pond operations (mixing and pumping) were calculated using the same protocol as Clarens et al. $(2010 ; 2011)^{1,23}$, Resurreccion et al. $(2012)^{2}$, and Bessette et al. (2018) . The cultivation utilized paddle wheels for mixing and the energy requirement was calculated using the following equation:

$$
\mathrm{P}=\frac{0.0037 \mathrm{~kJ} / \mathrm{s}}{\mathrm{PW}} * \frac{10 \mathrm{PW}}{\mathrm{ha}} * \frac{60 \mathrm{~s}}{\min } * \frac{60 \mathrm{~min}}{\mathrm{hr}} * \frac{24 \mathrm{hrs}}{\mathrm{day}} * \frac{365 \mathrm{days}}{\mathrm{yr}} * \frac{\mathrm{MJ}}{1000 \mathrm{~kJ}}=11,668 \frac{\mathrm{MJ}}{\mathrm{ha}-\mathrm{yr}} \quad \text { Equation S9 }
$$

The head $(17.78 \mathrm{~m})$ was estimated based on average distances that would be needed to transport the fluid between unit operations assuming moderate head losses associated with pipe fittings. The system head is generated from the following equation: 


$$
\mathrm{h}=\frac{\mathrm{P}_{2}-\mathrm{P}_{1}}{\rho \mathrm{g}} \quad \text { Equation } \mathrm{S10}
$$

where: $\mathrm{h}=$ system head $(\mathrm{m})$

$\mathrm{P} 2$ and $\mathrm{P} 1=$ pressure at the pump inlet $(0.1 \mathrm{MPa})$ and pump outlet $(0.2 \mathrm{MPa})$

$\rho=$ density of water $\left(\mathrm{kg} / \mathrm{m}^{3}\right)$

$\mathrm{g}=$ acceleration due to gravity $\left(9.8 \mathrm{~m} / \mathrm{s}^{2}\right)$

The water pumping energy requirement is then calculated using the following equation:

$$
\mathrm{W}=\frac{\mathrm{hg}}{\eta} * \dot{\mathrm{m}} \quad \text { Equation } \mathrm{S} 11
$$

where: $\mathrm{W}=$ water pumping energy requirement $(\mathrm{MJ} / \mathrm{ha})$

$\mathrm{h}=$ system head $(\mathrm{m})$

$\mathrm{g}=$ acceleration due to gravity $\left(9.8 \mathrm{~m} / \mathrm{s}^{2}\right)$

$\eta=$ pump efficiency $(85 \%)$

$\dot{\mathrm{m}}=$ the total mass of circulating pond water

\section{Preliminary Dewatering}

The dewatering of the algae biomass will be accomplished through autoflocculation and gravity thickening. Autoflocculation parameters are based on the research conducted by Spilling et al., $2011^{27}$ and the protocol used in Clarens et al. (2011) $)^{1,23}$, Resurreccion et al. (2012) ${ }^{2}$, and Bessette et al. (2018) where the increase in $\mathrm{pH}$ of the slurry to approximately 10.5 would cause the algae biomass to flocculate to a concentration factor of 10 via the addition of $\mathrm{PO}_{4}^{-}$. The requirement is $0.2 \mathrm{mM} \mathrm{PO}_{4}^{-}$in excess of the stoichiometric $\mathrm{P}$ demand. No additional chemical flocculants or energy is required. The thickening by gravity settling is based on an empirical regression equation developed by Soda et al., $2010^{19}$ and modeled in the work by Clarens et al. $(2011)^{1,23}$, Resurreccion et al. (2012) ${ }^{2}$, and Bessette et al. (2018) . The following equation was used and the resulting concentration factor of 10 is utilized in the model.

$$
y=636 x^{-1.04} \quad \text { Equation S12 }
$$

where: $y=$ electricity use rate for $100 x$ sludge load rate $(\mathrm{kWh} /$ ton dry solids)

$\mathrm{x}=100 \mathrm{x}$ sludge loading (ton dry solids/ha-day)

The energy use for this process is 7,600 MJ/ha-yr based upon a $39 \mathrm{Mg} / \mathrm{ha}$-yr loading rate. The output concentration was approximately $100 \mathrm{~g} / \mathrm{L}$ and it was assumed that this concentration is suitable for downstream processing $28-29$

\section{Homogenization and Lipid Extraction}

The dewatered algae biomass must have the lipids extracted in order to produce a biofuel product. This model uses homogenization to break down the algae cell walls for the subsequent lipid extraction. This model assumes mechanical homogenization with an energy demand of $67 \mathrm{MJ} / \mathrm{m}^{3}$ algae slurry for each homogenization pass and a cooling water consumption of $0.045 \mathrm{~m}^{3} / \mathrm{m}^{3}$ algae slurry per homogenization pass $^{28}$. This model assumes two homogenization passes with a total energy demand of 52,059 MJ/ha-yr. 
The homogenization passes are followed by a hexane extraction using a countercurrent cascade system of settler mixers. This model is based off of Stephenson et al. 201028. This process uses $0.02 \mathrm{MJ}$ electricity/L algae slurry, $0.75 \mathrm{~L}$ hexane/L algae slurry, and assumes a $99 \%$ efficiency. The extracted lipids have the free fatty acids removed by alkali refining which requires an input of heat $(155 \mathrm{MJ} / \mathrm{mg}$ algae oil), $\mathrm{NaOH}$ (24 $\mathrm{kg} \mathrm{NaOH} / \mathrm{Mg}$ algae oil), and water $\left(0.15 \mathrm{~m}^{3}\right.$ wash water $/ \mathrm{Mg}$ algae oil).

\section{Biodiesel Transesterification and Post Processing}

The refined algae oil is upgraded to biodiesel through the transesterification reaction. A glycerin coproduct is also produced. The process is a chemical cleavage od algae triglycerides into their constituent fatty acids (plus glycerin) and a subsequent conversion of each acid functional group into a fatty acid methyl ester (FAME). This is accomplished through a heated, base-catalyzed reaction of algae lipids and methanol (snare). The material and energy inputs can be seen in Table S7. The process assumes $96.3 \%$ efficiency. Post processing steps include washing with water to remove impurities, heat to recover methanol, and glycerin recovery. The total biodiesel produced in $4.4 \mathrm{Mg} / \mathrm{ha}$ and with a lower heating value of $37.7 \mathrm{MJ} / \mathrm{kg}^{28}$ this yields a total energy output of $166,775 \mathrm{MJ} / \mathrm{ha}$.

Table S7. Transesterification and post processing material and energy inputs.

\begin{tabular}{lr} 
& \multicolumn{1}{c}{ Material/Energy } \\
\hline Electricity & $118 \mathrm{MJ} / \mathrm{Mg}$ bio oil \\
Heat & $1,134 \mathrm{MJ} / \mathrm{Mg}$ bio oil \\
Acid $\left(37 \% \mathrm{HCl}\right.$ in $\left.\mathrm{H}_{2} \mathrm{O}\right)$ & $10 \mathrm{~kg} / \mathrm{Mg}$ biodiesel \\
Base $(\mathrm{KOH}$ to algae oil mass/mass) & $1.27 \%$ \\
Methanol & $103 \mathrm{~kg} / \mathrm{Mg}$ biodiesel \\
Cooling Water & $0.5725 \mathrm{~m}^{3} / \mathrm{Mg}$ biodiesel \\
Post process wash water & $278 \mathrm{~kg} / \mathrm{Mg}$ biodiesel \\
Heat for methanol/glycerin recovery & $653 \mathrm{MJ} / \mathrm{Mg}$ biodiesel \\
Acid for Glycerin recovery $10 \% \mathrm{HCl}$ in $\mathrm{H}_{2} \mathrm{O}$ & $75 \mathrm{~kg} / \mathrm{Mg}$ biodiesel \\
\hline
\end{tabular}

\section{Infrastructure}

The infrastructure requirements for algae cultivation and conversion into usable biofuel are calculated in the following paragraphs. All materials are annualized over a 30 -year life span. In this way, $1 / 30^{\text {th }}$ of the system infrastructure burdens are added to its annual operational burdens. The operational requirements are first calculated on a "per ha" basis and the multiplied by the functional unit. The capital requirements are calculated in the same way. The calculations for the functional units and direct land uses are expended upon in Section 8.

\subsection{Cultivation Infrastructure}

The three main materials required for algae open pond cultivation are polypropylene, aggregates, and polyvinyl chloride (PVC). Other equipment required are water pumps, flue gas pumps, and paddle wheels. The methodology for the evaluation of the open pond material and equipment requirements follows the methodology conducted in the research conducted by Resurreccion et al. (2012) ${ }^{2}$. Values obtained in Resurreccion et al. (2012) $)^{2}$ and Bessette et al. (2018) ${ }^{5}$ and were calculated using 2011 values therefore the 2017 cost of cultivation construction and materials was calculated using the historical inflation value equal an average of $1.45 \%$ over the last 6 years in the United States ${ }^{30}$. This methodology was utilized for the open pond liner, aggregates, liquid and gas piping, pumps, paddlewheels, and activated carbon filtration. 


\subsection{Conversion Infrastructure}

The infrastructure required for converting algae biomass into usable energy is a series of tanks which consist of the processes of autoflocculation, thickening, homogenization, lipid extraction, transesterification, biodiesel processing, solvent recovery, and activated carbon filtration. The methodology used for tank steel calculation was based on the study conducted by Resurreccion et al. $(2012)^{2}$ and Bessette et al. (2018) $)^{5}$ using the flow rate through each unit operation and the residence times for each process as seen in Table S8.

Table S8. Flow rates $(\mathrm{Q})$ from Table $\mathrm{S} 7$, residence times $(\tau)^{2}$, capacity volumes $\left(\mathrm{V}_{\text {TANK }}\right)$, capacity liquid weights $\left(\mathrm{M}_{\mathrm{LIQUI}}\right)$, and internal tank pressures $\left(\mathrm{P}_{\mathrm{TANK}}\right)$ required to compute tank steel demand $\left(\mathrm{M}_{\mathrm{TANK}}\right)$ for conversion unit operations following algae cultivation systems. $\mathrm{M}_{\text {TANK }}$ values are represented using units of "per hectare per year" because it is assumed that burdens associated with steel manufacture can be amortized over a 30-year useful life to compute the fraction of overall burden which should be charged to each year.

\begin{tabular}{lrrrrrr}
\multicolumn{1}{c}{ Unit Operations } & $\begin{array}{c}\mathrm{Q}, \\
\mathrm{m}^{3} / \mathrm{ha}-\mathrm{d}\end{array}$ & \multicolumn{1}{c}{$\mathrm{c}, \mathrm{d}$} & $\begin{array}{c}\mathrm{V}_{\text {LIQUID, }} \\
\mathrm{m}^{3} / \mathrm{ha}\end{array}$ & $\begin{array}{c}\mathrm{M}_{\text {LlQuID, }} \\
\mathrm{kg} / \mathrm{ha}\end{array}$ & $\mathrm{P}_{\text {TANK, }} \mathrm{Pa}$ & $\begin{array}{c}\mathrm{M}_{\text {TANK, }} \\
\mathrm{kg} / \mathrm{ha}-\mathrm{yr}\end{array}$ \\
\hline Autoflocculation & 118 & 0.1 & 11.5 & 11,100 & 22,112 & 43.0 \\
Thickening & 10.7 & 0.1 & 1.0 & 1,100 & 9,942 & 8.7 \\
Homogenization & 1.1 & 0.2 & 0.2 & 200 & 5,507 & 2.7 \\
Lipid Extraction & 1.1 & 0.03 & 0.04 & 40 & 3,264 & 0.9 \\
Solvent Recovery & 1.1 & 0.03 & 0.04 & 40 & 3,250 & 0.9 \\
Transesterification & 1.1 & 0.03 & 0.04 & 40 & 3,264 & 0.9 \\
Biodiesel Post-Processing & 1.1 & 0.03 & 0.04 & 40 & 3,264 & 0.9 \\
Anaerobic Digestion & 108 & 14 & 1515 & $1,515,400$ & 112,565 & 1,115 \\
Activated Carbon Filtration & 0.88 & 0.014 & 0.012 & 12 & 2,261 & 0.5 \\
\hline
\end{tabular}

\section{Calculation of reported LCA Metrics}

\subsection{Functional Unit and Direct Land Use}

The functional unit (FU) for this LCA study is effectively the energy required to sustain 902 people and assumed to be $20,000 \mathrm{MJ} / \mathrm{yr}$. This unit represents the required energy and food products required to sustain the community as well as the waste stream generated from those individuals and processes required to keep the community functioning. The base model is created in a way that inputs and outputs are on a per hectare basis. By choosing to modify the amount of land designated to algae cultivation, all results are subsequently modified. The energy content of Scenedesmus sp. is assumed to be $23 \mathrm{MJ} / \mathrm{kg}^{4}$. The areal productivity of Scenedesmus sp. is assumed to be $41.6 \mathrm{Mg} / \mathrm{ha}^{2,31}$. The initial model uses calculated land required algae cultivation in order to produce $20,000 \mathrm{MJ} / \mathrm{yr}$ of energy from MSW and biodiesel production ( $0.02 \mathrm{ha}$ ). Further iterations of this model are evaluated for the effect of optimizing the algae cultivation in order to achieve an energy return on investment (EROI) $=1$ and again to achieve a profitability index $(\mathrm{PI})=1$.

\subsection{Energy Return on (Energy) Investment (EROI)}

Energy ratios of the type reported by Hall and Klitgaard ${ }^{32}$, Hall et al..$^{33}$, Luo et al. $(2010)^{34}$, Clarens et al. (2011) $)^{1}$, and Resurreccion et al. (2012) $)^{2}$ were computed to determine the energy production in terms of net positive or negative energy totals. The EROI was computed using the energy output as the numerator and energy input is used as denominator. Values greater than one are said to be net energy-producing which is desirable, and values less than one are said to be net-energy consuming. Larger values are deemed more desirable from a life cycle perspective, and it's been suggested that the minimum tenable 
EROI is roughly 3 (i.e., $3 \mathrm{MJ}$ energy delivered per $1 \mathrm{MJ}$ consumed) but that values between 5 and 10 will ultimately be required to maintain the present quality of life once fossil fuels are no longer readily abundant ${ }^{2}$. The EROI numerator included biofuel production (biodiesel and methane). Components of the EROI denominator (energy input) included: direct electricity and heat use, residential energy usage, and upstream energy use for materials and energy inputs (as computed using Ecoinvent ${ }^{\circledR}$ impact factors Section 9).

\subsection{Net Global Warming Potential (NGR)}

The GWP was calculated similarly to the calculations performed in Resurreccion et al. $(2012)^{2}$ and Bessette et al (2018) ${ }^{31}$. The GWP ratio evaluates GHG emissions performance on a normalized basis. The GHG outputs (emitting processes) are used as numerator and GHG uptakes (sequestering processes) are used as denominator. A favorable GWP is expressed as a number less than one. This equates to a net-GHG consuming system. The NGR numerator consists of energy inputs (electricity and natural gas) and material inputs (fertilizer, infrastructure materials, hexane, granulated carbon, etc.). The NGR denominator consists of the sequestration of the photosynthesis $\mathrm{CO}_{2}$ and soil amendment offsets.

\section{LCA Impact Factors}

Inputs are required to produce the energy and materials one functional unit in the systems. Impact factors used in this study were taken from the industry-standard Ecoinvent ${ }^{\circledR}$ database. These are summarized in Table S9.

Table S9. Life cycle impact factors for materials and energy inputs used in all models, as expressed using

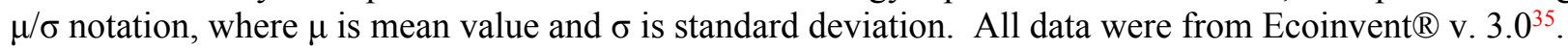

\begin{tabular}{|c|c|c|c|}
\hline Item & Unit Basis & Energy Use (MJ) & $\mathrm{GHG}\left(\mathrm{kg} \mathrm{CO} \mathrm{CO}_{2}\right.$ eq \\
\hline Aggregates & $1 \mathrm{~kg}$ gravel & $0.04 / 0.007$ & $0.003 / 0.0004$ \\
\hline Bleach & $1 \mathrm{~kg} 15 \% \mathrm{NaOCl}$ in $\mathrm{H}_{2} \mathrm{O}(\mathrm{m} / \mathrm{m})$ & $10.2 / 4.0$ & $0.9 / 0.1$ \\
\hline Carbon Dioxide & $1 \mathrm{~kg} \mathrm{CO} 2$ & $8.3 / 2.0$ & $0.8 / 0.1$ \\
\hline Concrete & $1 \mathrm{~m}^{3}$ & $1180.0 / 836.0$ & $265.0 / 47.7$ \\
\hline Electricity & $1 \mathrm{kWh}$ from US grid & $12.5 / 10.1$ & $0.2 / 0.01$ \\
\hline Fertilizer $-\mathrm{N}_{2} \mathrm{H}_{4} \mathrm{CO}$ & $1 \mathrm{~kg}$ as $\mathrm{N}$ & $62.1 / 11.8$ & $3.4 / 0.3$ \\
\hline Fertilizer $-\mathrm{H}_{12} \mathrm{~N}_{3} \mathrm{O}_{4} \mathrm{P}$ & $1 \mathrm{~kg} \mathrm{P}_{2} \mathrm{O}_{5}$ & $37.5 / 5.4$ & $0.8 / 0.07$ \\
\hline Fertilizer - $\mathrm{CaH}_{2} \mathrm{P}_{2} \mathrm{O}_{8}$ & $1 \mathrm{~kg} \mathrm{P}_{2} \mathrm{O}_{5}$ & $33.8 / 14.5$ & $2.7 / 0.5$ \\
\hline Glycerin & $1 \mathrm{~kg} \mathrm{C}_{3} \mathrm{H}_{5}(\mathrm{OH})_{3}$ & $8.7 / 1.2$ & $1.7 / 0.2$ \\
\hline Granulated Carbon & $1 \mathrm{~kg} \mathrm{GC}$ & 1.6 & 8.66 \\
\hline Heat & $1 \mathrm{MJ}$ from light heating oil & $1.3 / 0.2$ & $0.1 / 0.01$ \\
\hline Hexane & $1 \mathrm{~kg} \mathrm{C}_{6} \mathrm{H}_{14}$ & $59.7 / 3.3$ & $0.9 / 0.09$ \\
\hline Hydrochloric acid & $1 \mathrm{~kg} 30 \% \mathrm{HCl}$ in in $\mathrm{H}_{2} \mathrm{O}(\mathrm{m} / \mathrm{m})$ & $10.4 / 3.1$ & $0.9 / 0.2$ \\
\hline Methanol & $1 \mathrm{~kg} \mathrm{CH}_{3} \mathrm{OH}$ & $37.7 / 5.5$ & $0.8 / 0.07$ \\
\hline Natural Gas & $1 \mathrm{~kg}$ Natural Gas & 4.2 & 0.007 \\
\hline Polymethyl methacrylate & $1 \mathrm{~kg}\left(\mathrm{C}_{3} \mathrm{H}_{8} \mathrm{O}_{2}\right)_{\mathrm{n}}$ & $132.0 / 0.08$ & $8.3 / 0.009$ \\
\hline Polypropylene & $1 \mathrm{~kg}\left(\mathrm{C}_{3} \mathrm{H}_{6}\right)_{\mathrm{n}}$ & $70.7 / 0.01$ & $2.0 / 0.0007$ \\
\hline Polyvinyl chloride & $1 \mathrm{~kg}\left(\mathrm{C}_{2} \mathrm{H}_{3} \mathrm{Cl}\right)_{\mathrm{n}}$ & $47.2 / 3.6$ & $2.0 / 0.1$ \\
\hline Pump (Water/Flue Gas)* & 1 piece & $0.3 / 0.06$ & $0.01 / 0.002$ \\
\hline Sodium hydroxide & $1 \mathrm{~kg} 50 \% \mathrm{NaOH}$ in $\mathrm{H}_{2} \mathrm{O}(\mathrm{m} / \mathrm{m})$ & $11.2 / 4.6$ & $8.0 / 1.3$ \\
\hline Steel & $1 \mathrm{~kg}$ steel $(>10.5 \% \mathrm{Cr})$ & $62.3 / 19.9$ & $59.3 / 3.1$ \\
\hline
\end{tabular}




\section{Economics}

The economic feasibility was then conducted for the model. The economic analysis was conducted by calculating the initial capital and outlay costs and the annual operations cash flows over the 30-year project lifetime. An economically attractive project is able to recoup the capital outlay costs over a short amount of time given a prevailing discount rate. This project assumes a $12 \%$ discount rate. Results from the simulation yielded cash flows (annual operating costs, annual revenues) and total initial outlay, respectively: From these cash flows and total initial outlay, profitability index (PI) is derived. PI is calculated as the ratio of the net present value (NPV) of the expected future cash flows and the total initial outlay. This ratio is meaningful insofar as it reflects the relative share of expected income throughout project's life as a percent of total expenditure incurred at the beginning of the project. An economicallyfeasible project has $\mathrm{PI}>1$. Projects with $\mathrm{PI}<1$ are considered not profitable.

\subsection{Initial and Annual Cash Flows}

Initial Outlay and Capital Costs. Components of initial outlay/capital costs include infrastructure costs, major equipment costs (MEC), and miscellaneous expenses ${ }^{36}$. Infrastructure costs are associated with the establishment of physical assets including land, buildings, roads, and electrical distribution. MECs are associated with procurement of heavy machinery (pumps, paddle wheels, etc) and other unit operations paraphernalia (tanks, etc). Miscellaneous expenses refer to extraneous costs such as start-up costs, working capital, and engineering and contingencies.

Annual Cash Flows. Annual cash flows (annuities) are calculated as the difference between revenues

and operating costs. Revenues are positive cash flows from sale of the biofuel product and the biofuel coproducts and may also include credits. Operating costs are negative cash flows. There are four major categories of operating costs: process costs, energy costs, indirect costs, and depreciation. Process costs include procurement of raw materials (e.g., $\mathrm{CO}_{2}$ and nutrients) and labor. Energy costs include payments for electricity and heat required to operate cultivation and conversion equipment. Indirect costs include fees for waste disposal, infrastructure maintenance, and insurance. Annual depreciation is the percentage of initial outlay apportioned to the use of major equipment during one year of operation ${ }^{37}$. Although depreciation may be viewed as a "non-cash" cost, it is categorized as a negative cash flow and counted against annual revenue.

Incremental cash flows can be calculated once annual revenues and operating costs are determined. This requires a series of calculations. First, before-tax earnings (gross income) are calculated as the difference between revenues and operating costs. Then, after-tax earnings (net income) are determined based on the prevailing tax rate (39\% was assumed for this study which is equivalent to $23.6 \%$ as the effective marginal tax rate (EMTR). This is a suitable measure of tax rate because it applies to investment projects where the pretax return is just enough to break even after taxes) ${ }^{38}$. Depreciation is then added to generate annual gross cash flow.

It is important to note that this community is designed to be self-sustaining and revenue/profitability is not the ultimate goal of this project. It has been found that there is a shortfall of the $\mathrm{CO}_{2}$ requirement for the algae cultivation without diesel generator operation therefore the sale of biodiesel may offset the cost of $\mathrm{CO}_{2}$.

\subsection{Costs Data Collection}

Every effort was made to ensure that economic models were based on current economic data. The cost of land was calculated using the average value of commercial farmland in Georgia ${ }^{39}(\$ 3,500 / \mathrm{ha})$. Many 
construction and major equipment costs (e.g., clearing, excavation, grading) were extracted the study conducted by Resurreccion et al. (2012) $)^{2}$ and updated using the average inflation rate over the last 6 years $(1.45 \%)^{30}$. Costs for some items specific to the algae industry were taken from Benemann and Oswald ${ }^{24}$ and updated using average historical inflation values ${ }^{30}$. The steel used for operations were modeled assuming a Grade 55 carbon steel construction using a five-sided cubic geometry. The top cover is assumed to be of a material which is significantly lighter, cheaper, and less environmentally burdensome than steel. The minimum steel plate thickness is $1 / 4$ " which is appropriate for pressure in the range of 207 $\mathrm{MPa}$ according to the ASME Pressure Vessel Code and ASTM A516. Results for steel burdens were annualized over 30 years. Costs for electricity, heat, and pertinent materials values were determined from US Energy Information Administration ${ }^{40-41}$. The pump requirements were scaled on a $40-\mathrm{kW}$ nominal rating in order to evaluate impacts on an equivalent power basis using an assumed 30-year useful life annualization burden.

Table S10. Cost data pertains to initial outlays for open pond system biodiesel production and MSW Digestion generating a 20,000 MJ/yr (0.02 ha), an EROI = 1 ( $0.18 \mathrm{ha})$, and a PI = 1 (1.55 ha).

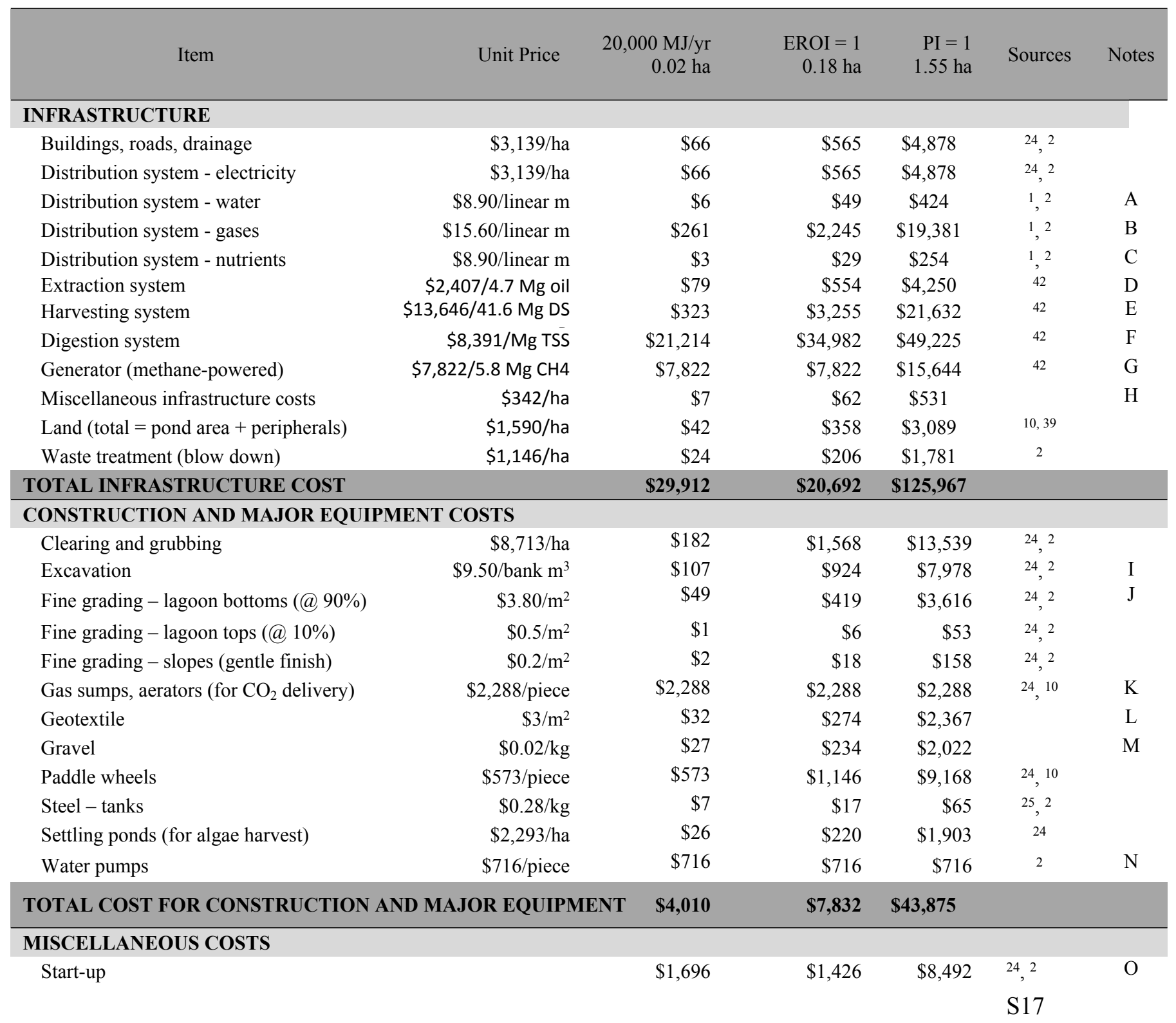




\begin{tabular}{|c|c|c|c|c|c|}
\hline Engineering and contingencies & $\$ 5,088$ & $\$ 4,279$ & $\$ 25,476$ & 24,2 & $\mathrm{P}$ \\
\hline Working capital & $\$ 40,706$ & $\$ 34,229$ & $\$ 203,810$ & 24,2 & Q \\
\hline TOTAL MISCELLANEOUS COSTS & $\$ 16,961$ & $\$ 14,262$ & $\$ 84,921$ & & $\mathrm{R}$ \\
\hline TOTAL INITIAL OUTLAY & $\$ 50,883$ & $\$ 42,787$ & $\$ 254763$ & & \\
\hline
\end{tabular}

A. Assume $100 \mathrm{ft} / \mathrm{ha}(30.5 \mathrm{~m} / \mathrm{ha})$ for algae media, water supply; PVC Class 150, 3"-diameter; excludes excavation or backfill.

B. Assume 800 m/ha; polyethelyene, 60 PSI, 1.25"-diameter, @100' ft, coupling, SDR 11, excludes excavation or backfill.

C. Assume $60 \mathrm{ft} / \mathrm{ha}(18.3 \mathrm{~m} / \mathrm{ha})$ for inflows of nutrient solution.

D. $\$ 16,000,000$ extraction cost per $34,065 \mathrm{Mg}$ oil produced/year. Our oil yield is $4.7 \mathrm{Mg}$ oil/year.

E. $\$ 41,000,000$ harvesting cost per 136,260 Mg DS produced/year. Our DS yield is $41.6 \mathrm{Mg}$ DS/year.

F. $\$ 23,000,000$ digestion cost per $102,195 \mathrm{Mg}$ TSS produced/year. Our TSS yield is $34.2 \mathrm{Mg}$ TSS/year.

G. $\$ 15,167$ generator cost per $12.26 \mathrm{Mg} \mathrm{CH} 4$ produced/yr. Our CH4 yield is $5.8 \mathrm{Mg} \mathrm{CH} 4 /$ year.

H. Assumed price per hectare includes service facilities, instrumentation, and machinery.

I. Excavated areas are as follows: long ends, cones, divider levees, interior levees, top circles, bottom circles. Total excavated volume is $47.7 \mathrm{~m}^{3}$ per 1-ha. Total area to be excavated is $481 \mathrm{~m}^{2}$ per ha. Price assumes trench or continuous footing, common earth, 3/8 CY excavator, 1-4' deep; excludes sheeting or dewatering.

J. Lagoon bottoms to be graded for paving with grader; lagoon tops to be graded for compaction.

K. Lake aeration system, 110/220-volt motor, 9.2 amp@ (110v), 4.8amp @ (220v), 10psi-10.0 cfm open air flow (pumps air to 20' depth).

L. Geotextile dimensions are calculated as twice the walkway area to account for the slopes: $\left(2 * 4658^{*} \mathrm{x} \mathrm{ha} / \mathrm{FU} * 0.05\right)=41 \mathrm{~m}^{2} / \mathrm{ha}$ (a) $5 \%$.

M. Compacted gravel layer is 4'-deep, covering $10 \%$ of pond area, mostly near paddlewheels and other erosion-prone areas.

N. Price based on Pentair Whisperflo pool pump: controllable, single phase, 2 HP.

O. $5 \%$ of total infrastructure cost AND total cost for construction and major equipment.

P. $15 \%$ of total infrastructure cost AND total cost for construction and major equipment.

Q. 25\% of total direct capital.

R. Sum of total infrastructure cost, total cost for construction and major equipment, start-up, and engineering and contingencies.

Table S11. Annual cash flows for open pond system biodiesel production and MSW Digestion generating a 20,000 MJ/yr (0.02 ha), an EROI = 1 (0.18 ha), and a PI = 1 (1.55 ha).

\begin{tabular}{|c|c|c|c|c|c|}
\hline Item & $\begin{array}{r}20,000 \\
\mathrm{MJ} / \mathrm{yr}\end{array}$ & $\begin{array}{r}\text { EROI = } 1 \\
0.18 \text { ha }\end{array}$ & $\begin{array}{c}\mathrm{PI}=1 \\
1.55 \text { ha }\end{array}$ & Sources & Notes \\
\hline \multicolumn{6}{|l|}{ REVENUES } \\
\hline Total biodiesel produced@ @ \$2.68/gallon & $\$ 75$ & $\$ 640$ & $\$ 5,525$ & \multirow{3}{*}{$\begin{array}{l}40 \\
43\end{array}$} & A \\
\hline Net bioelectricity to grid @ $\$ 0.12 / \mathrm{kWh}$ & $\$ 0$ & $\$ 379$ & $\$ 34,986$ & & $\mathrm{~B}$ \\
\hline Fertilizer substitute credits @ \$425/Mg & $\$ 0$ & $\$ 2$ & $\$ 18$ & & $\mathrm{C}$ \\
\hline TOTAL REVENUES & $\$ 75$ & $\$ 1,021$ & $\$ 40,529$ & & \\
\hline \multicolumn{6}{|l|}{ EXPENSES AND OPERATING COSTS } \\
\hline \multicolumn{6}{|l|}{ PROCESS COSTS } \\
\hline $\mathrm{CO}_{2}$ (from recycled flue gas) @ $\$ 44 / \mathrm{Mg} \mathrm{CO}_{2}$ & $\$ 44$ & $\$ 344$ & $\$ 117$ & \multirow{2}{*}{$\begin{array}{l}43 \\
43\end{array}$} & \\
\hline Nutrients@ $@ \$ 463 / \mathrm{Mg} \mathrm{H}_{22} \mathrm{~N}_{3} \mathrm{O}_{4} \mathrm{P}$ & $\$ 0$ & $\$ 0$ & $\$ 0$ & & \\
\hline Labor and overhead & $\$ 19$ & $\$ 166$ & $\$ 1,431$ & 43 & $\mathrm{D}$ \\
\hline Other miscellaneous materials & $\$ 2$ & $\$ 17$ & $\$ 143$ & & $\mathrm{E}$ \\
\hline \multicolumn{6}{|l|}{ ENERGY COSTS } \\
\hline Direct electricity@\$0.12/kWh & $\$ 13$ & $\$ 73$ & $\$ 631$ & \multirow[t]{2}{*}{40} & \\
\hline Other power & $\$ 8$ & $\$ 60$ & $\$ 232$ & & $\mathrm{~F}$ \\
\hline \multicolumn{6}{|l|}{ INDIRECT COSTS } \\
\hline Waste Disposal & $\$ 11$ & $\$ 66$ & $\$ 431$ & \multirow{2}{*}{$\begin{array}{l}24,2 \\
24,2\end{array}$} & G \\
\hline Maintenance and insurance & $\$ 63$ & $\$ 87$ & $\$ 282$ & & $\mathrm{H}$ \\
\hline TOTAL EXPENSES AND OPERATING COSTS & $\$ 1,608$ & $\$ 2,811$ & $\$ 9,862$ & & \\
\hline \multicolumn{6}{|l|}{ INCREMENTAL CASH FLOWS } \\
\hline (-) Depreciation & $\$ 1,447$ & $\$ 1,998$ & $\$ 6,588$ & \multirow[t]{2}{*}{44} & \multirow[t]{3}{*}{ I } \\
\hline Operating income & $\$-1,533$ & $\$-1,790$ & $\$ 30,667$ & & \\
\hline (-) Tax (at 23.6\%) & $\$-362$ & $-\$ 422$ & $\$ 7,237$ & 38 & \\
\hline
\end{tabular}


Net operating profit after tax (NOPAT)

(+) Depreciation

GROSS ANNUAL CASH FLOW
$\$-1,171$

$\$ 1,447$
$\$-1,367$

$\$ 1,998$
$\$ 23,430$

$\$ 6,588$

$\$ 30,018$

A.Biodiesel yield (in $\mathrm{Mg} / \mathrm{ha}) \times$ direct land use (in ha) $\times 7.14$ barrels $/ \mathrm{Mg}$ biodiesel $) \times 42$ gallon/barrel $\times \$ 2.68 /$ gallon .

B. Total energy (in MJ/ha) - Methane yield (in $\mathrm{kg} / \mathrm{ha}$ ) x Methane energy $(50 \mathrm{MJ} / \mathrm{kg}) \times$ direct land use (in ha) $\times \$ 0.04 / \mathrm{kWh}$.

C. Fertilizer substitute revenues are computed based on quantities of diammonium phosphate and urea that could be supplanted via use of digestate as alternative fertilizer, based on bioavailabilty equivalence between commercial fertilizers and the algae digestate on an $\mathrm{N}$ basis.

D. $\$ 10 / \mathrm{hr} \times 8 \mathrm{hrs} /$ day x 330 days/yr x 1 person/50 ponds x 1 pond/ha x direct land use. Overhead assumed to be $60 \%$ of labor.

E. Assumed to be $10 \%$ of labor and overhead.

F. Assumed to be $10 \%$ of process cost and direct energy.

G.Assumed to be $50 \%$ of total energy cost.

H.Annual maintenance and insurance is assumed to be $3.5 \%$ of the respective depreciable bases (Benemann and Oswald (1996).

I. Calculated assuming an 11-year MACRS depreciation schedule ${ }^{44}$ and a $23.6 \%$ average marginal tax rate for the US ${ }^{38}$.

\section{References}

1. Clarens, A. F.; Nassau, H.; Resurreccion, E. P.; White, M. A.; Colosi, L. M., Environmental impacts of algae-derived biodiesel and bioelectricity for transportation. Environmental science \& technology 2011, 45 (17), 7554-7560, http://dx.doi.org/10.1021/es200760n.

2. Resurreccion, E. P.; Colosi, L. M.; White, M. A.; Clarens, A. F., Comparison of algae cultivation methods for bioenergy production using a combined life cycle assessment and life cycle costing approach. Bioresource Technology 2012, 126, 298-306, http://dx.doi.org/10.1016/j.biortech.2012.09.038.

3. Yang, P. P.-J.; Quan, S. J.; Castro-Lacouture, D.; Stuart, B. J., A Geodesign method for managing a closed-loop urban system through algae cultivation. Applied Energy 2018, 231, 1372-1382, https://doi.org/10.1016/i.apenergy.2017.12.129.

4. McGinn, P. J.; Dickinson, K. E.; Park, K. C.; Whitney, C. G.; MacQuarrie, S. P.; Black, F. J.; Frigon, J.-C.; Guiot, S. R.; O'Leary, S. J., Assessment of the bioenergy and bioremediation potentials of the microalga Scenedesmus sp. AMDD cultivated in municipal wastewater effluent in batch and continuous mode. Algal Research 2012, 1 (2), 155-165, https://doi.org/10.1016/j.algal.2012.05.001.

5. Bessette, A. P.; Teymouri, A.; Martin, M. J.; Stuart, B. J.; Resurreccion, E. P.; Kumar, S., Life cycle impacts and techno-economic implications of flash hydrolysis in algae processing. ACS Sustainable Chemistry \& Engineering 2018, 6 (3), 3580-3588, https://doi.org/10.1021/acssuschemeng.7b03912. 6. USDA Food Patterns. https://www.cnpp.usda.gov/USDAFoodPatterns (accessed February 2018). 7. One Acre Feeds a Person- Farmland LP. http://www.farmlandlp.com/2012/01/one-acre-feeds-aperson/ (accessed February 2018).

8. USDA Georgia State Agricultural Overview. https://www.nass.usda.gov/Quick Stats/Ag Overview/stateOverview.php?state=GEORGIA (accessed May 2019).

9. Flachowsky, G.; Meyer, U.; Südekum, K.-H., Land use for edible protein of animal origin-A review. Animals 2017, 7 (3), 1-19.

10. Livanis, G.; Moss, C. B.; Breneman, V. E.; Nehring, R. F., Urban sprawl and farmland prices. American Journal of Agricultural Economics 2006, 88 (4), 915-929, https://doi.org/10.1111/j.14678276.2006.00906.x.

11. Deru, M.; Field, K.; Studer, D.; Benne, K.; Griffith, B.; Torcellini, P.; Liu, B.; Halverson, M.; Winiarski, D.; Rosenberg, M., US Department of Energy commercial reference building models of the national building stock. 2011, 1.

12. Heidner, A. F.; Heidner, D. L. In A long-term case study of improved residential sustainability: Moving from energy hog to low energy use intensity, Technologies for Sustainability (SusTech), 2013 1st IEEE Conference on, IEEE: 2013; pp 29-36. 
13. U.S. Census Historical Households Tables. https://www.census.gov/data/tables/timeseries/demo/families/households.html (Accessed March 2018).

14. Bishop, J., Profiles on residential power consumption. The Fire Protection Research Foundation 2010, 1-42.

15. US Energy Information Administration- Generator Construction Cost Data. https://www.eia.gov/electricity/generatorcosts/ (Accessed March 2018).

16. 2500kW MTU 16V4000 Emissions Data Sheet. 2012.

17. Kaabeche, A.; Ibtiouen, R., Techno-economic optimization of hybrid photovoltaic/wind/diesel/battery generation in a stand-alone power system. Solar Energy 2014, 103, 171-182, https://doi.org/10.1016/j.solener.2014.02.017.

18. Pecorini, I.; Olivieri, T.; Bacchi, D.; Paradisi, A.; Lombardi, L.; Corti, A.; Carnevale, E., Evaluation of gas production in a industrial anaerobic digester by means of Biochemical Methane Potential of Organic Municipal Solid Waste Components. Proteins 2012, 33 (1), 0-24.

19. Soda, S.; Iwai, Y.; Sei, K.; Shimod, Y.; Ike, M., Model analysis of energy consumption and greenhouse gas emissions of sewage sludge treatment systems with different processes and scales. Water Science and Technology 2010, 61 (2), 365-373, https://doi.org/10.2166/wst.2010.827.

20. Carey, R. O.; Migliaccio, K. W., Contribution of wastewater treatment plant effluents to nutrient dynamics in aquatic systems: a review. Environmental Management 2009, 44 (2), 205-217, https://doi.org/10.1007/s00267-009-9309-5.

21. Masters, G. M.; Ela, W., Introduction to environmental engineering and science. Prentice Hall Englewood Cliffs, NJ: 1991; Vol. 3.

22. Nigussie, A.; Kuyper, T. W.; Neergaard, A. d., Agricultural waste utilisation strategies and demand for urban waste compost: Evidence from smallholder farmers in Ethiopia. Waste Management 2015, 44, 82-93, https://doi.org/10.1016/i.wasman.2015.07.038.

23. Clarens, A. F.; Resurreccion, E. P.; White, M. A.; Colosi, L. M., Environmental life cycle comparison of algae to other bioenergy feedstocks. Enivronmental Science \& Technology 2010, 44 (5), 1813-1819, http://dx.doi.org/10.1021/es902838n.

24. Benemann, J. R.; Oswald, W. J. Systems and economic analysis of microalgae ponds for conversion of $\mathrm{CO}$ \{sub 2$\}$ to biomass. Final report; University of California, Berkeley, CA (United States). Dept. of Civil Engineering: 1996.

25. Kadam, K. L., Environmental implications of power generation via coal-microalgae cofiring. Energy 2002, 27 (10), 905-922, http://dx.doi.org/10.1016/S0360-5442(02)00025-7.

26. Redfield, A. C., The biological control of chemical factors in the environment. American Scientist 1958, 46 (3), 230A-221.

27. Spilling, K.; Seppälä, J.; Tamminen, T., Inducing autoflocculation in the diatom Phaeodactylum tricornutum through CO2 regulation. Applied Phycology 2011, 23 (6), 959-966, http://dx.doi.org/10.1007/s10811-010-9616-5.

28. Stephenson, A. L.; Kazamia, E.; Dennis, J. S.; Howe, C. J.; Scott, S. A.; Smith, A. G., Life-cycle assessment of potential algal biodiesel production in the United Kingdom: a comparison of raceways and air-lift tubular bioreactors. Energy \& Fuels 2010, 24 (7), 4062-4077, https://doi.org/10.1021/ef1003123.

29. Golueke, C. G.; Oswald, W. J., Harvesting and processing sewage-grown planktonic algae. Journal (Water Pollution Control Federation) 1965, 37 (4), 471-498, https://www.jstor.org/stable/25035278.

30. US Inflation Calculator. http://www.usinflationcalculator.com/inflation/current-inflation-rates/ (accessed July 2017).

31. Bessette, A. P.; Teymouri, A.; Martin, M. J.; Stuart, B. J.; Resurreccion, E. P.; Kumar, S., Life cycle impacts and techno-economic implications of flash hydrolysis in algae processing. ACS Sustainable Chemistry \& Engineering 2018, 6 (3), 3580-3588, https://doi.org/10.1021/acssuschemeng.7b03912. 
32. Hall, C.; Klitgaard, K., The need for a new, biophysical-based paradigm in economics for the second half of the age of oil. International Journal of Transdisciplinary Research 2006, 1 (1), 4-22.

33. Hall, C. A.; Balogh, S.; Murphy, D. J., What is the minimum EROI that a sustainable society must have? Energies 2009, 2 (1), 25-47, http://dx.doi.org/10.3390/en20100025.

34. Luo, D.; Hu, Z.; Choi, D. G.; Thomas, V. M.; Realff, M. J.; Chance, R. R., Life cycle energy and greenhouse gas emissions for an ethanol production process based on blue-green algae. Environmental science \& technology 2010, 44 (22), 8670-8677, http://dx.doi.org/10.1021/es1007577

35. Weidema, B., Ecoinvent data v3.0.

36. Grima, E. M.; Belarbi, E.-H.; Fernández, F. A.; Medina, A. R.; Chisti, Y., Recovery of microalgal biomass and metabolites: process options and economics. Biotechnology Advances 2003, 20 (7), 491515, https://doi.org/10.1016/S0734-9750(02)00050-2.

37. Ross, S. A., Corporate finance: core principles \& applications. Irwin/McGraw-Hill: 2007.

38. Hassett, K. A.; Mathur, A., Report card on effective corporate tax rates: United States gets an F. Korea 2011, 22, 20-24.

39. US Department of Agriculture.

https://www.nass.usda.gov/Publications/Todays Reports/reports/land0818.pdf (accessed June 2019).

40. US Energy Information Administration - Electricity. http://www.eia.gov/electricity/wholesale/ (accessed July 2017).

41. US Energy Information Administration - Natural Gas. https://www.eia.gov/naturalgas/ (accessed July 2017).

42. Davis, R.; Aden, A.; Pienkos, P. T., Techno-economic analysis of autotrophic microalgae for fuel production. Applied Energy 2011, 88, 3524-3531, http://dx.doi.org/10.1016/j.apenergy.2011.04.018

43. Handy, S. L., Accessibility-vs. mobility-enhancing strategies for addressing automobile dependence in the US. UC Davis: Institute of Transportation Studies 2002, 1-34.

44. How to Depreciate Property - IRS Instructional Form CAT No. 13081F. Service, U. I. R., Ed.

Washington D.C., 2011; pp 27-50. 